\title{
SOSIALISASI INVESTASI SYARIAH DI
} MASYARAKAT

\author{
${ }^{1)}$ Hendro Lisa, ${ }^{2)}$ Martina Napratilora \\ 1)2) STAI Auliaurrasyidin Tembilahan \\ 1)hendro.lisa@stai-tbh.ac.id ${ }^{2}{ }^{\text {martina.napratilora@stai-tbh.ac.id }}$
}

\begin{abstract}
Abstrak
Perkembangan pasar modal syariah, salah satunya didukung oleh peranan berbagai pihak terutama dalam melakukan sosialisasi dan edukasi. Penelitian bertujuan mengidentifikasi peran sosialisasi dan edukasi terhadap minat investasi di pasar modal syariah. Data-data yang digunakan dalam penyusunan karya tulis ini berasal dari berbagai literatur kepustakaan yang berkaitan dengan permasalahan yang dibahas. Jenis data yang diperoleh variatif, baik yang bersifat kualitatif maupun kuantitatif. Metode penulisan bersifat studi pustaka.
\end{abstract}

Keyword : Pasar Modal, Syariah, Edukasi, Minat 


\section{A. Pendahuluan}

Secara umum pengertian dari investasi adalah penanaman asset atau dana yang dilakukan oleh sebuah perusahaan atau perorangan untuk jangka waktu tertentu demi memperoleh imbal balik yang lebih besar dimasa depan. Ada banyak hal yang terlibat dalam aktivitas ini, dan beberapa diantaranya adalah jumlah dana dan tujuan dari investasi itu sendiri. Bagi yang sudah lama melibatkan diri dalam penanaman modal, baik lokal maupun internasional. Istilah berinvestasi bukanlah sesuatu yang asing. Namun bagi pemula, penjelasan singkat dan jelas mengenai pengertian dasar dan cara berinvestasi sangatlah dibutuhkan.

Perkembangan pasar modal syariah, salah satunya didukung oleh peranan berbagai pihak terutama dalam melakukan sosialisasi dan edukasi. Sosialisasi dan edukasi dilakukan untuk masyarakat, baik institusi maupun perorangan, dan sosialisasi secara nasional maupun internasional. Tujuan sosialisasi dan edukasi, salah satunya adalah untuk meningkatkan investor di pasar modal. Di samping itu juga untuk meningkatkan kepercayaan investor terhadap pasar modal syariah. Berbagai dukungan tersebut pada faktanya belum menemui hasil yang diharapkan. Hasil Survei Literasi Keuangan dalam Roadmap Pasar Modal Syariah, mayoritas masyarakat Indonesia (lebih dari 90\%) masih belum mengenal pasar modal. Penggunaan instrumen pasar modal masih sedikit, yakni hanya kurang dari 1\%. Jika dibandingkan dengan Negara-negara Asia lainnya.

Indonesia seharusnya memiliki potensi yang tinggi dalam hal jumlah investor syariah, karena mayoritas penduduk Indonesia adalah muslim. Rendahnya minat investasi ini disebabkan karena kurangnya edukasi dan sosialisasi terutama berkaitan dengan efek syariah. 
Dengan demikian, penelitian bertujuan mengidentifikasi peran sosialisasi dan edukasi terhadap minat investasi di pasar modal syariah. Secara khusus penelitian ini bertujuan untuk mengidentifikasi berbagai sosialisasi dan edukasi yang sudah dilakukan, mengidentifikasi peranan media sosialisasi terhadap minat investasi, serta mengidentifikasi factor pendukung dan penghambat.

\section{B. Metodologi}

Data-data yang digunakan dalam penyusunan karya tulis ini berasal dari berbagai literatur kepustakaan yang berkaitan dengan permasalahan yang dibahas. Beberapa jenis referensi utama yang digunakan adalah buku pelajaran ekonomi, jurnal ilmiah dan modul yang didapat melalui edisi cetak maupun edisi online, dan artikel-artikel ilmiah yang bersumber dari internet. Jenis data yang diperoleh variatif, baik yang bersifat kualitatif maupun kuantitatif.

Metode penulisan bersifat studi pustaka. Informasi yang didapatkan dari berbagai literature dan disusun berdasarkan hasil studi dari informasi yang diperoleh. Penulisan diupayakan saling terkait antara satu sama lain sesuai dengan topik yang dibahas.

Data yang terkumpul dan diurutkan sesuai dengan topik kajian. Kemudian dilakukan penyusunan karya tulis berdasarkan data yang telah dipersiapkan secara logis dan sistematis. Teknik analisis data bersifat deskriktif dan argumentative.

Simpulan didapatkan setelah merujuk kembali pada rumusan masalah, tujuan penulisan, serta pembahasan. Simpulan ditarik mempresentasikan pokok bahasan karya tulis, serta didukung dengan saran praktis sebagai rekomendasi selanjutnya. 


\section{Hasil dan Pembahasan}

Investasi pada umumnya merupakan suatu istilah dengan beberapa pengertian yang berhubungan dengan keuangan dan ekonomi, to use (money) make more mone out of something that expected to increase in value. Istilah tersebut berkaitan dengan akumulasi suatu bentuk aktiva dengan harapan mendapatkan keuntungan di masa depan. Terkadang, investasi disebut juga sebagai penanaman modal.

Artinya, investasi dapat diartikan sebagai pengeluaran yang ditujukan untuk meningkatkan atau mempertahankan stok barang modal (Aziz, 2010). Stok barang modal (capital stocks) terdiri dari pabrik, mesin, kantor, dan produk-produk tahan lama lainnya yang digunakan dalam proses produksi. Barang modal juga meliputi perumahan tempat tinggal dan juga persediaan.

Investasi adalah komitmen atau sejumlah dana atau sumber daya lainnya yang dilakukan pada saat ini, dengan tujuan memperoleh sejumlah keuntungan dimasa datang (Tendelilin, 2001). Istilah investasi bisa berkaitan dengan berbagai macam aktivitas. Menginvestasikan dana pada sekor rill (tanah, emas, mesin atau bangunan) maupun asset financial (deposito, saham atau obligasi), merupakan aktifitas yang umum di lakukan.

Menurut Jogiyanto, investasi dapat didefinisikan sebagai penundaan konsumsi sekarang untuk digunakan dalam produksi yang efisien selama periode tertentu (Jogiyanto, 2003). Sedangkan menurut Sukirno kegiatan investasi yang dilakukan oleh masyarakat secara terus menerus akan meningkatkan pendapatan kegiatan ekonomi dan kesempatan kerja, meningkatkan pendapatan nasional dan meningkatkan taraf kemakmuran masyarakat. Peranan ini bersumber dari tiga fungsi penting dari kegiatan investasi, yakni (1) investasi merupakan salah satu komponen dari pengeluaran agregat, sehingga kenaikan investasi akan meningkatkan 
permintaan agregat, pendapatan nasional serta kesempatan kerja. (2) pertambahan barang modal sebagai akibat investas akan menambah kapasitas produksi, (3) investasi selalu diikuti oleh perkembangan teknologi (Nizar, dkk, 2011)

Investasi syariah adalah sebuah investasi berbasis syariah yang menggunakan instrumen islam dalam pelaksanaannya. Ada beberapa jenis investasi berdasarkan jangka waktu, resiko dan prosesnya. Hal-hal tersebut perlu diketahui guna memastikan ketepatan antara alasan dan cara melakukan investasi (Isnawan 2012).

Menurut jangka waktunya

a. Investasi jangka pendek, yaitu investasi yang dilakukan tidak lebih dari 12 bulan.

b. Investasi jangka menengah, yaitu investasi yang memiliki rentang waktu antara 1 hingga 5 tahun.

c. Investasi jangka panjang, yaitu investasi yang jangka waktunya lebih dari 5 tahun.

Menurut risiko

Setiap pilihan investasi akan berkaitan dengan dua hal, risiko dan return. Keduanya merupakan hubungan sebab dan akibat dan hubungan yang saling kontradiktif. Dalam teori investasi dikenal istilah "high risk high return, low risk low return".

Dalam bahasa Arab, risiko dapat diartikan sebagai gharar. Yang kadang juga merujuk pada ketidakpastian (uncertainty). Kalau kemudian risiko ini secara sederhana disamakan dengan ketidakpastian, dan ketidakpastian ini dianggap gharar dan di larang, maka akan menjadi rumit. 
Karenanya menjadi penting untuk melakukan upaya pembedaan dan penajaman pengertian gharar atau risiko.

Seperti yang dilakukan oleh Al-Suwailem yang membedakan risiko menjadi dua tipe. Yakni yang pertama adalah risiko pasif, seperti game of chance yang hanya mengandalkan keberuntungan. Kedua, risiko responsif yang memungkinkan adanya distribusi probabilitas hasil keluaran dengan hubungan kausalitas yang logis.

Ketidakpastian secara intrinsik terkandung dalam setiap aktivitas ekonomi. Tetapi, ketidakpastian kejadian tetap mengikuti suatu kausalitas atau sebab akibat yang logis yang bisa mempengaruhi probabilitasnya. Ini berarti, mencari keuntungan hanya dengan keberuntungan saja, seperti membeli lotre, menimbulkan delusi atau pengharapan yang salah, dan sudah pasti merupakan transaksi gharar.

Dari penjelasan-penjelasan tersebut, dapat ditarik benang merah bahwa sebuah transaksi yang gharar dapat timbul karena dua sebab utama. Pertama, adalah kurangnya informasi atau pengetahuan pada pihak yang melakukan kontrak. Dalam hal ini menyebabkan tidak dimilikinya control pada pihak yang melakukan transaksi. Kedua, karena tidak adanya obyek.

Kemudian menurut pontjiwoto, risiko yang mungkin timbul harus dikelola sehingga tidak menimbulkan risiko yang lebih besar atau melebihi kemampuan menanggung risiko. Dan dalam islam setiap transaksi yang mengharapkan hasil harus bersedia menanggung risiko.

Menurut prosesnya

a. Investasi langsung, yaitu investasi yang dilakukan tanpa bantuan perantara. Dalam hal ini investor langsung dapat membeli portofolio investasi tersebut. 
b. Investasi tidak langsung, yaitu investasi yang dilakukan dengan menggunakan perantara atau investasi yang dilakukan melalui perusahaan investasi.

A. Bentuk- Bentuk Investasi Syariah

Investasi atau pembentukan modal, merupakan salah satu sumber pertumbuhan ekonomi (sumber lain SDM, teknologi, SDA dan lain-lain). Menurut produknya, investasi dapat dibagi menjadi dua jenis, yaitu produk investasi di sector rill seperti: wiraswasta, property, tanah, komoditi, emas dan lain-lain; dan di sektor keuangan, seperti tabungan, deposito, obligasi, reksadana, saham dan future serta sejenisnya.

Produk investasi di sektor keuangan, hanya dapat dilaksanakan pada pasar perdana maupun pasar sekunder. Pasar perdana merupakan pasar ketika perusahaan pertama kali menjual saham kepada masyarakat (go public) sehingga menjadi pasar perusahaan public (Tbk). Sementara, pasar sekunder merupakan pasar terorganisasi (bursa efek) yang memfasilitasi perdagangan saham-saham yang telah dicatatkan (listed company).

Berbeda daripada itu, pada umumnya dalam investasi konvensional, bentuk investasi ada 3 pokok, yaitu:

1. Investasi tanah, diharapkan dengan bertambahnya populasi dan penggunaan tanah, harga tanah akan meningkat di masa depan.

2. Investasi pendidikan, dengan bertambahnya pengetahuan dan keahlian, diharapkan pencarian kerja dan pendapatan lebih besar.

3. Investasi saham, diharapkan perusahaan mendapatkan keuntungan dari hasil kerja atau penelitin.

Menurut Muhammad Budi Setiawan, bentuk- bentuk investasi syariah dapat dikelompokkan pada dua jenis yaitu : 
1. Deposito Syariah

Dalam operasionalnya di dunia perbankan, transaksi ini mempunyai karakteristik tersendiri, yaitu kedua belah pihak yang mengadakan kontrak antara pemilik dana dan mudharib akan menentukan kapasitas baik sebagai nasabah maupun pemilik. Di dalam akad tercantum pernyataan yang harus dilakukan kedua belah pihak yang mengadakan kontrak dengan ketentuan sebagai berikut:

a. Di dalam perjanjian tersebut harus dinyatakan secara tersurat maupun tersirat mengenai tujuan kontrak.

b. Penawaran dan penerimaan harus disepakati kedua belah pihak di dalam kontrak tersebut.

c. Maksud penawaran dan penerimaan merupakan suatu kesatuan informasi yang sama penjelasannya. Perjanjian bisa saja berlangsung melalui proposal tertulis dan langsung ditandatangani.

Modal adalah sejumlah uang pemilik dana yang diberikan mudharib untuk diinvestasikan (dikelola) dalam kegiatan usaha mudharabah.

a. Jumlah modal harus diketahui secara pasti termasuk jenis mata uangnya.

b. Modal harus dalam bentuk tunai, seandainya berbentuk asset menurut Jumhur Ulama Fiqh diperbolehkan, asalkan berbentuk barang niaga dan mempunyai nilai atau historinya pada saat mengadakan kontrak. Bila asset tersebut berbentuk non-kas yang siap dimanfaatkan, seperti pesawat dan kapal, menurut mazhab Hanbali diperbolehkan sebagai modal mudharabah asalkan mudharbib tetap menginvestasikan semua modal tersebut dan berbagi hasil dengan pemilik dana dalam pendapatan dari investasi dan pada akhir tahun jangka waktu.

c. Modal harus tersedia dalam bentuk tunai tidak dalam bentuk piutang.

d. Modal mudharabah langsung dibayar kepada mudharib. Beberapa Fuqaha berbeda pendapat mengenai cara realisasi pencarian dana, yaitu 
dibayar langsung dengan cara lain dilaksanakan dengan memungkinkan mudharib untuk memperoleh manfaat dari modal tersebut bagaimanapun cara akuisisinya. Sesuai dengan pendapatan kedua, pengadaan kontrak dapat dilaksanakan untuk keseluruhan modal dan pembayarannya kepada mudharib dapat dibuat dalam beberapa angsuran.

Keuntungan adalah jumlah yang melebihi jumlah modal dan merupakan tujuan mudharabah dengan syarat-syarat sebagai berikut:

a. Keuntungan ini haruslah berlaku bagi kedua belah pihak dan tidak ada pihakpun yang akan memilikinya.

b. Haruslah menjadi perhatian dari kedua belah pihak dan tidak terdapat pihak kegika yang akan turut memperoleh bagi hasil darinya. Porsi bagi hasil keuntungan untuk masing-masing pihak harus disepakati bersama pada saat perjanjian ditandatangani. Bagi hasil mudharib harus secara jelas dinyatakan pada saat pengadaan kontrak dilakukan.

c. Pemilik dana akan menanggung semua kerugian sebaliknya mudharib tidak menanggung kerugian sedikit pun. Akan tetapi, mudharib harus menanggung kerugian bila kerugian itu timbul dari pelanggaran perjanjian atau penghilangan dana tersebut.

Jenis usaha/pekerjaan diharapkan mewakili/menggambarkan adanya kontribusi mudharib dalam usahanya untuk mengembalikan/membayar modal kepada penyedia dana. Jenis pekerjaan dalam hal ini berhubungan dengan masalah manajemen dari pembiayaan muhdarabah itu sendiri. Di bawah ini merupakan syarat-syarat yang harus diterapkan dalam usaha/pekerjaan mudharabah:

a. Bentuk pekerjaan/usaha. Merupakan hak khusus mudharib tidak ada intervensi manajemen dari pemilik dana, meskipun demikian menurut Mazhab Hambali membolehkan adanya peran serta/partisipasi pemilik dana dalam pekerjaan/usaha tersebut. 
b. Penyedia dana tidak harus boleh membatasi kegiatan mudharib seperti melarang mudharib agar tidak sukses dalam pencarian laba/keuntungan.

c. Mudharib tidak boleh melanggar hukum islam dalam usahanya dan juga harus mematuhi praktik-praktik usaha yang berlaku.

d. Mudharib harus mematuhi syarat-syarat yang diajukan pemilik dana asalkan syarat-syarat tersebut tidak bertentangan kontrak mudharabah tersebut.

Modal mudharabah tidak boleh dalam penguasaan pemilik dana, sehingga tidak dapat ditarik sewaktu-waktu. Penarikan dana mudharabah hanya dapat dilakukan sesuai dengan waktu yang disepakati (periode yang telah ditentukan). Penarikan dana yang dilakukan setiap saat akan membawa dampak berkurangnya pembagian hasil usaha oleh nasabah yang menginvestasikan dananya.

2. Pasar Modal Syariah

Dalam arti sempit pengertian pasar merupakan tempat para penjual dan pembeli bertemu untuk melakukan transaksi, artinya pembeli dan penjual langsung bertemu untuk melakukan transaksi dalam suatu lokasi tertentu. Lokasi atau tempat pertemuan tersebut disebut pasar. Namun dalam arti luas pengertian pasar merupakan tempat melakukan transaksi antara pembeli dan penjual, dimana pembeli dan penjual tidak harus bertemu dalam suatu tempat atau bertemu langsung, akan tetapi dapat dilakukan melalui sarana informasi yang ada seperti sarana elektronika.

Pengertian pasar modal secara umum merupakan suatu tempat bertemunya para penjual dan pembeli untuk melakukan transaksi dalam rangka memperoleh modal. Penjual (emiten) dalam pasar modal merupakan perusahaan yang membutuhkan modal, sehingga mereka berusaha untuk menjual efek di pasar modal. Sedangkan pembeli (investor) adalah pihak yang ingin membeli modal di perusahaan yang menurut mereka 
menguntungkan. Pasar modal dikenal dengan nama bursa efek. Di Indonesia dikenal dengan nama Bursa Efek Indonesia.

Sedangkan pengertian dari pasar modal syariah sebagaimana yang didefinisikan oleh Dewan Pengawas Syariah Nasional (DSN) Nomor : 40/DSN-MUI/X/2003 Tentang Pasar Modal dan Pedoman Umum Penerapan Prinsip Syariah di Bidang Pasar Modal adalah :

a. Pasar modal adalah kegiatan yang bersangkutan dengan Penawaran Umum dan Perdagangan Efek, Perusahaan Publik yang berkaitan dengan efek yang diterbitkannya, serta lembaga dan profesi yang berkaitan dengan efek.

b. Pasar modal beserta seluruh mekanisme kegiatannya terutama mengenal emiten, jenis efek yang diperdagangkan dan mekanisme perdagangannya dipandang telah sesuai dengan syariah apabila telah memenuhi prinsipprinsip syariah.

Jadi, pasar modal syariah adalah kegiatan yang bersangkutan dengan Penawaran Umum dan Perdagangan Efek, perusahaan public yang berkaitan dengan efek yang diterbitkannya serta lembaga dan profesi yang berkaitan dengan efek yang menjalankan kegiatannya sesuai dengan prinsipprinsip syariah islam.

Modal yang diperdagangkan dalam pasar modal merupakan modal yang bila diukur dari waktunya merupakan jangka panjang. Oleh karena itu bagi emiten sangat menguntungkan mengingat masa pengembaliannya relative panjang, baik yang bersifat kepemilikan maupun yang bersifat hutang. Khusus untuk modal bersifat kepemilikan, jangka waktunya lebih panjang jika dibandingkan dengan yang bersifat hutang.

B. Perbedaan Investasi Syariah dengan Konvensional

Dengan absennya bunga dalam perekonomian dewasa ini, hubungan investasi dan tabungan dalam perekonomian islam "tidak sekuat" seperti yang ada dalam perekonomian konvensional. Dalam konvensional 28 
hubungan investasi dan tabungan dihubungkan oleh peran bunga dalam perekonomian. Sehingga bunga menjadi indikator fluktasi yang terjadi di investasi dan tabungan. Ketika bunga (bunga simpanan dan bungan pinjaman) tinggi maka kecenderungan tabungan akan meningkat, sementara investasi relative turun.

Begitu sebaliknya, ketika bunga rendah, maka tabungan akan menurun dan investasi akan meningkat. Dengan demikian dapat dikatakan bahwa motivasi dalam aktivitas tabungan dan investasi dalam konvensional didominasi oleh motif keuntungan (return) yang bisa didapatkan dari keduanya.

Sedangkan dalam persepektif ekonomi islam, investasi bukanlah melulu bercerita tentang berupa keuntungan materi yang bisa didapatkan melalui ativitas investasi, tapi ada beberapa factor yang mendominasi motivasi investasi dalam islam (Aziz, 2010).

1. Dikarenakan inplementasi mekanisme zakat maka asset produktif yang dimiliki seseorang pada jumlah tertentu (memenuhi batas nisahab zakat) akan selalu dikenakan zakat, sehigga hal ini akan mendorong pemiliknya untuk mengelolanya melalui investasi. Dengan demikian melalui investasi tersebut pemilik asset memiliki potensi mempertahankan jumlah dan nilai asetnya. Berdasarkan argumentasi ini, aktvitas investasi pada dasarnya lebih dekat dengan prilaku individu (investor/muzakki) atas kekayaan atau asset mereka daripada perilaku individu atas simpanan mereka.

2. Adanya motivasi social yaitu membantu sebagian masyarakat yang tidak memiliki modal namun memiliki kemampuan berupa keahlian dalam menjalankan usaha, baik dilakukan dengan bersyarikat (musyarakah) maupun bagi hasil (mudharabah).

Dalam aplikasi investor sector rill konvensional juga lazimnya memang berbeda dengan aplikasi syariah. Di konvensional aktivitas 
investasi lekat dengan konsep bunga dimana setiap investasi yang terjadi diasumsikan selalu berakhir untung (postif). Investasi konvensional tidak mengakomodasi kemungkinan rugi. Berbeda dengan syariah, system ini menggunakan konsep bagi-rugi hasil (mudharabah) dimana asumsi dasarnya adalah kefitrahan usaha yang dapat untung dan dapat pula rugi. Sebagaimana ilustrasi gambar di bawah ini, M. Akhyar Adnan (Aziz, 2010) menjelaskan dalam sebuah kurva di bawah ini :

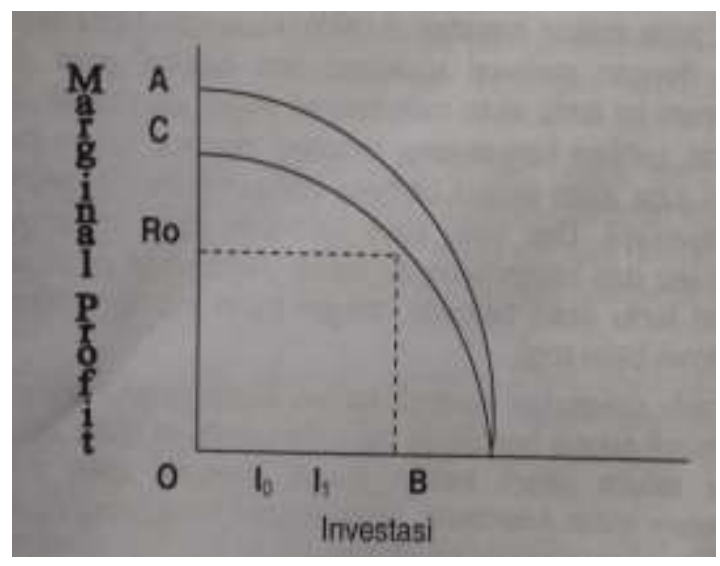

Garis vertical menggambar marginal profit yakni selisih antara gross sale revenue dengan seluruh cost selain pembayaran terhadap modal. Sedangkan sumbu horizontal adalah investasi. Kurva AB dan $\mathrm{CB}$ adalah gambaran investasi dan marginal profit. $\mathrm{CB}$ merupakan pengurangan terhadap $\mathrm{AB}$ yang persentasi tetap atas share marginal profit yang harus diberikan kepada pemilik modal, karena dipakai pendekatan profit sharing. Wilayah $\mathrm{OB}$ dan $\mathrm{BC}$ adalah hak pengusaha, sedangkan $\mathrm{AB}$ dan $\mathrm{BC}$ adalah hak yang diterima oleh pemilik modal.

Dengan mengumpakan bahwa tingkat bunga adalah ORo, maka dalam sistem ekonomi kapitalisme, investasi akan berhenti pada posisi OIo, karena investasi yang melebihi titik ini akan menghasilkan kerugian, Karena tambahan investasi yang akan menghasilkan biaya yang lebih besar dibandingkan tambahan laba. Sebaliknya, dalam investasi syariah, investasi 
bisa mencapai jarak OI1, karena tambahan investasi sampai dengan OI1 masih memberikan laba, baik bagi pengusaha maupun pemilik modal.

C. Keuntungan Investasi

Khusus untuk saham, peluang keuntungan dan risiko yang mungkin timbul antara lain:

\section{Capital Gain}

Yaitu keuntungan dari hasil jual beli saham berupa kelebihan nilai jual dari nilai beli saham. Misalnya sewaktu membeli nilainya Rp.2000 persaham dan kemudian dijual dengan harga Rp.2.500 ini disebut capital gain (keuntungan dari modal).

Saham adalah surat berharga yang paling populer di antara surat berharga yang ada di pasar modal. Karena bila dibandingkan investasi lainnya, saham memungkinkan pemodal untuk mendapatkan return atau keuntungan yang lebih besar dalam waktu yang relative singkat (high return).

Selain high return, saham juga memiliki sifat high risk, yaitu suatu ketika harga saham dapat juga merosot lebih cepat, atau sahamnya di-delist (dihapuskan pencatatannya) dari bursa sehingga untuk jual beli harus mencari pembeli/penjual sendiri dan saham tidak lagi memiliki haarga patokan pasar. Dengan karakteristik high risk return ini maka pemodal perlu terus memantau pergerakan harga saham yang dipegangnya, agar keputusan yang tepat dapat dihasilkan dalam waktu yang tepat pula.

\section{Dividen}

Merupakan keuntungan perusahaan yang dibagikan kepada pemegang saham. Biasanya tidak seluruh keuntungan perusahaan yang dibagikan kepada pemegang saham, tetapi ada bagian yang ditanam kembali. Besarnya dividen yang diterima ditentukan dalam Rapat Umum Pemegang Saham (RUPS) perusahaan tersebut. Namun yang perlu dicatat adalah bahwa perusahaan tidak selalu membagikan dividen kepada para 
pemegang saham tetapi tergantung kepada kondisi perusahaan itu sendiri (khususnya berkaitan dengan keuntungan yang diraih). Artinya jika perusahaan mengalami kerugian tentu saja dividen tidak akan dibagikan pada tahun berjalan tersebut (Aziz, 2010).

D. Resiko Investasi

Investasi selain juga dapat menambah penghasilan seseorang juga membawa risiko keuangan bilamana investasi tersebut gagal. Kegagalan beinvestasi disebabkan oleh banyak hal, diantaranya adalah faktor keamanan (baik dari bencana alam atau diakibatkan faktor manusia), ketertiban hukum, dan lain-lain.

Secara umum, resiko dapat diartikan sebagai ketidakpastian dari kerugian (uncertainty of loss). Definisi yang sederhana ini mengandung dua unsur yaitu 1) ketidakpastian (uncertainty), dan 2) kerugian (loss). Istilah resiko (risk) dapat juga dalam arti benda atau objek pertanggungan (subject matter insured) dan bencana/ bahaya (perils). Kapal, muatan barang, mobil, bangunan, dan lain-lain adalah beberapa contoh dari benda-benda pertanggungan. Angin ribut, gempa bumi, banjir, pencurian adalah beberapa contoh dari perils atau bencana/bahaya yang dapat menimbulkan kerugian bila terjadi.

Dalam buku "Panduan Pemodal/ Investasi di Pasar Modal", yang diterbitkan Indonesia Stock Exchange atau yang dikenal dengan Bursa Efek Indonesia, pada umumnya resiko investasi dibagi menjadi dua macam resiko utama, yaitu: ${ }^{1}$

1. Capital loss

Capital loss merupakan kebalikan dari capital gain, yaitu suatu kondisi dimana Investor menjual saham yang dimilikinya di bawah harga belinya. Misalnya, saham PT. ABC dibeli Investor dengan harga Rp.2000 
persaham, kemudian saham tersebut terus mengalami penurunan hingga mencapai Rp.1.400 per saham.

Karena takut harga saham tersebut akan terus menurun, maka investor kemudian menjual pada harga tersebut sehingga investor mengalami kerugian sebesar Rp.600 per saham. Itulah capital loss yang menimpa investor.

2. Risiko likuiditas

Perusahaan yang sahamnya dimiliki, dinyatakan bangkrut oleh pengadilan atau perusahaan tersebut dibubarkan. Dalam hal ini hak klaim dari pemegang saham mendapat prioritas terakhir setelah seluruh kewajiban saham dapat dilunasi (dari hasil penjualan kekayaan perusahaan). Jika masih terdapat sisa dari hasil penjualan kekayaan perusahaan tersebut, maka sisa tersebut dibagi secara proporsional kepada seluruh pemegang saham.

Namun jika tidak terdapat sisa kekayaan perusahaan, maka pemegang saham tidak akan memperoleh apa-apa. Ini merupakan resiko yang terberat dari seorang pemegang saham. Untuk itu seorang saham turut dituntut secara terus menerus mengikuti perkembangan dari perusahaan yang sahamnya dimiliki.

E. Sosialiasi Investasi Terhadap Masyarakat

Perkembangan pasar modal syariah, salah satunya didukung oleh peranan berbagai pihak terutama dalam melakukan sosialisasi dan edukasi (Gunawan, 2011). Sosialisasi dan edukasi dilakukan untuk masyarakat, baik institusi maupun perorangan, dan sosialisasi secara nasional maupun internasional (OJK, 2015). Sosialisasi dan edukasi di lingkungan kampus secara langsung meliputi seminar, workshop, pelatihan, simulasi dan kompetisi baik tingkat regional maupun nasional, bahkan sampai tingkat internasional. Sementara, sosialiasi dan edukasi yang tidak langsung yaitu dengan cara memanfaatkan media, baik media elektronik, media cetak maupun media online. 
Di samping menggunakan model tersebut, untuk meningkatkan pengetahuan mahasiswa terhadap pasar modal syariah dilakukan dengan cara menawarkan mata kuliah pasar modal syariah, maupun mata kuliah yang berkaitan dengan investasi yang di dalamnya dibahas materi tersebut.Di samping itu, untuk semakin memperluas pemahaman mahasiswa beberapa universitas yang bekerja sama dengan PT Bursa Efek Indonesia. Bentuk kerjasama tersebut yaitu dengan terdapatnya galeri investasi. Adanya galeri investasi ini bertujuan untuk memberikan fasilitas kepada mahasiswa untuk dapat mengakses segala informasi tentang pasar modal. Bahkan mahasiswa juga dapat mengakses praktik langsung melalui silamulasi trading. Dukungan dari perusahaan sekuritas pun juga dilakukan, terutama dalam memberikan akses kemudahan bagi para mahasiswa untuk mulai membuka rekening dan memulai trading, yaitu hanya dengan Rp.100.000,00 sudah dapat melakukan transaksi.

Tujuan sosialisasi dan edukasi, salah satunya adalah untuk meningkatkan investor di pasar modal. Di samping itu juga untuk meningkatkan kepercayaan investor terhadap pasar modal syariah (Yanti, dkk, 2012). Berbagai dukungan tersebut pada faktanya belum menemui hasil yang diharapkan. Hasil Survei Literasi Keuangan dalam Roadmap Pasar Modal Syariah (OJK, 2019), mayoritas masyarakat Indonesia (lebih dari $90 \%$ ) masih belum mengenal pasar modal. Penggunaan instrumen pasar modal masih sedikit, yakni hanya kurang dari 1\%. Jika dibandingkan dengan Negara-negara Asia lainnya.

Indonesia seharusnya memiliki potensi yang tinggi dalam hal jumlah investor syariah, karena mayoritas penduduk Indonesia adalah muslim. Rendahnya minat investasi ini disebabkan karena kurangnya edukasi dan sosialisasi terutama berkaitan dengan efek syariah. Dengan demikian, penelitian bertujuan mengidentifikasi peran sosialisasi dan edukasi terhadap minat investasi di pasar modal syariah (Supriyadi dan 
Hariyanto, 2016). Secara khusus penelitian ini bertujuan untuk mengidentifikasi berbagai sosialisasi dan edukasi yang sudah dilakukan, mengidentifikasi peranan media sosialisasi terhadap minat investasi, serta mengidentifikasi faktor pendukung dan penghambat (Mubarok, 2018).

1. Peranan sosial media dalam menginformasikan atau mensosialisasikan kepada para responden tentang pasar modal syariah.

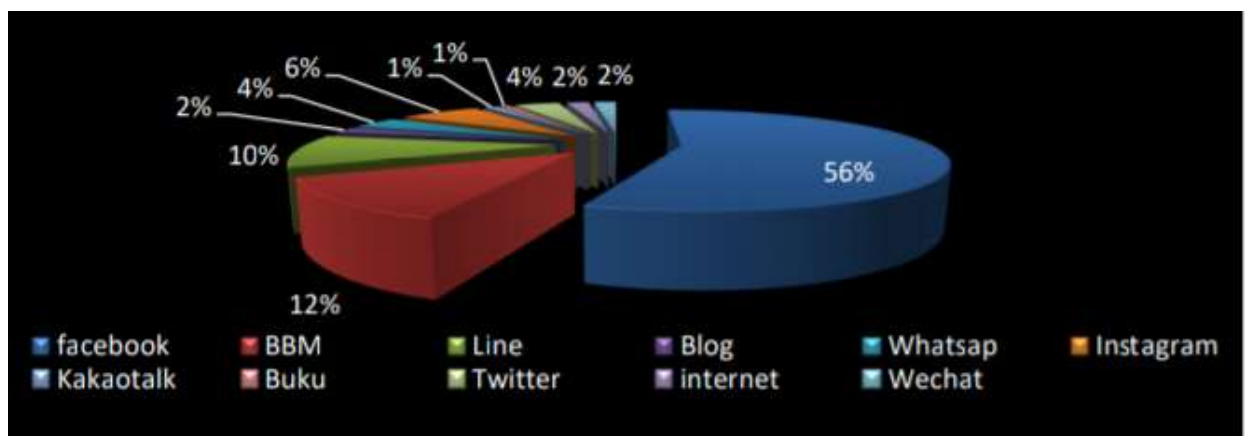

Dari gambar di atas telihat bahwa peranan media social melalui facebook sangat besar yaiutu 56\%, lalu disusul dengan BBM 12\%, Line $10 \%$, Instagram 6\%, Whatsap 4\%, Twitter 4\%, Wechat 2\%, Blog 2\%, Buku $1 \%$, dan kakaotalk $1 \%$.

2. Peranan sosialisasi dan edukasi dalam membangun minat investasi

Berdasarkan data, peran masing-masing media sosialisasi dan edukasi cukup beragam dan masing-masing juga memiliki pengaruh yang berbeda-beda terhadap minat para mahasiswa untuk berinvestasi di pasar modal syariah. Peran media sosialisasi menurut responden, antara lain melalui workshop atau seminar maupun pelatihan, media perkuliahan, buku, media cetak, media social, media internet, galeri investasi, dan PIPM (Pusat Informasi Pasar Modal), berdasarkan data menunjukkan bahwa yang paling berperan cukup besar sebagai media sosialisasi dan edukasi adalah media internet, sedangkan yang paling kecil kontribusinya adalah PIPM. PIPM cukup rendah kontribusinya, karena dari beberapa responden belum mengenal apa yang dimaksud dengan PIPM. 


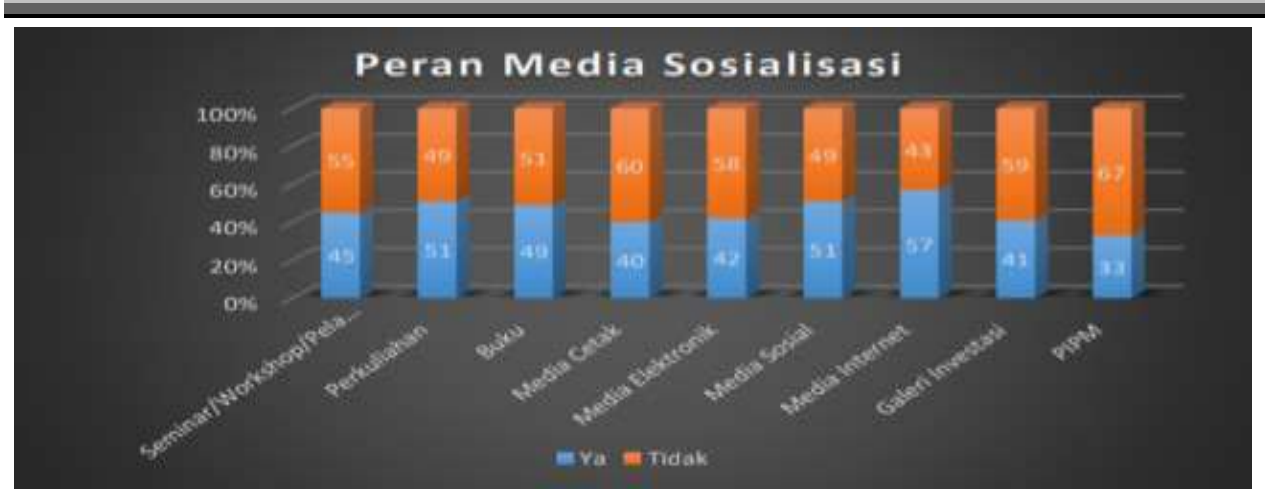

Media sosialisasi dan edukasi tersebut, disamping memiliki peran untuk memberikan informasi kepada para calon investor, ternyata juga memiliki dampak atau pengaruh kepada para mahasiswa untuk beinvestasi di pasar modal syariah. Masing-masing memiliki pengaruh yang berbeda, sebagaimana tampak pada gambar di bawah ini.

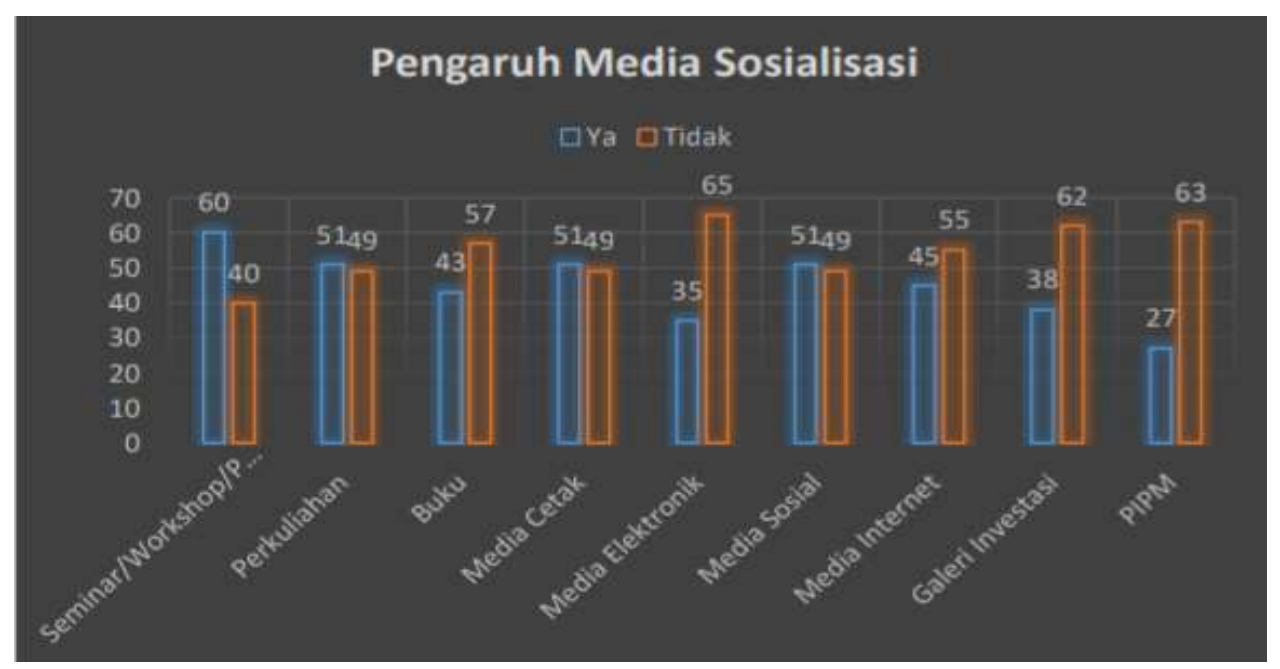

3. Faktor- faktor yang mendukung minat dan yang menghambat investasi

Untuk membangun minat investasi mahasiswa memang diperlukan pendekatan khusus, salah satunya melalui sosialisasi dan edukasi yang mampu menarik perhatian mereka. Secara umum sebagian responden pada dasarnya berminat untuk investasi. Hal ini ditunjukkan sebanyak $73 \%$ responden menjawab berminat untuk berinvestasi di pasar modal syariah, dan hanya $27 \%$ responden yang menjawab tidak berminat. Salah satunya 36 
alasan para responden berinvestasi adalah adanya pengetahuan para responden tentang pasar modal syariah. Gambar di bawah ini menunjukkan pengetahuan mahasiswa tentang pasar modal syariah.

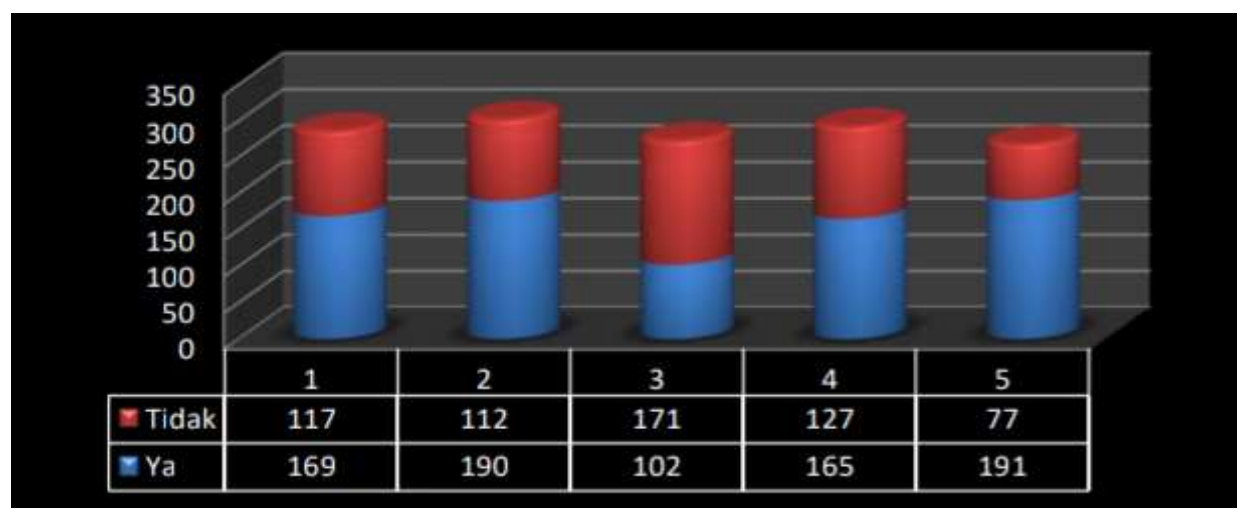

Berdasarkan data yang diperoleh bahwa sebagian dari responden sudah mengetahui perbedaan antara pasar modal konvensional dan syariah, yaitu ditunjukkan pada diagram batang dengan kode 1 yang mana sebesar $52 \%$ responden sudah mengetahui perbedaan. Sementara itu sisanya $48 \%$ responden belum bisa membedakan keduanya. Para responden juga sudah mulai mengetahui berbagai instrumen di pasar modal syariah, yang mana ditunjukkan dengan diagram batang kode 2 yang menunjukkan bahwa 57\% responden menjawab demikian. Sementara itu sisanya $43 \%$ responden belum mengetahui berbagai instrumen yang ada di pasar modal syariah. Temuan berikutnya adalah pengetahuan mengenai indeks yang tergabung dalam indeks syariah, yang mana ditunjukkan oleh diagram batang kode 3 . Pada gambar tersebut hanya menunjukkan bahwa pengetahuan tentang indek tersebut masih sangat rendah yaitu hanya ada $25 \%$ responden, sementara sisanya $75 \%$ belum mengetahui.

Temuan lain tentang pengetahuan berbagai sektor di pasar modal syariah, dalam hal ini ditunjukkan oleh diagram kode 4, yang mana hanya 
ada $47 \%$ responden yang mengetahui berbagai sektor yang ada di dalam pasar modal syariah. Sementara itu, sisanya 53\% belum mengetahuinya. Temuan berikutnya adalah mengenai pengetahuan responden risiko yang akan dihadapi ketika berinvestasi di pasar modal syariah. Dalam hal ini ditunjukkan oleh diagram batang dengan kode 5, yang menunjukkan bahwa responden yang sudah mengenai informasi tersebut sebanyak $64 \%$. Sementara sisanya $36 \%$ responden belum mengetahui berbagai risiko yang dihadapi ketika berinvestasi di pasar modal syariah. Dengan pengetahuan yang sudah berkembang, para responden pada dasarnya berminat untuk investasi. Hal ini terutama dilihat dari motivasi rsponden dalam rangka investasi di pasar modal syariah, yang dapat dikategorikan sebagai faktor yang mendukung para responden untuk ivestasi di pasar modal. Faktorfaktor tersebut tampak di dalam gambar berikut.

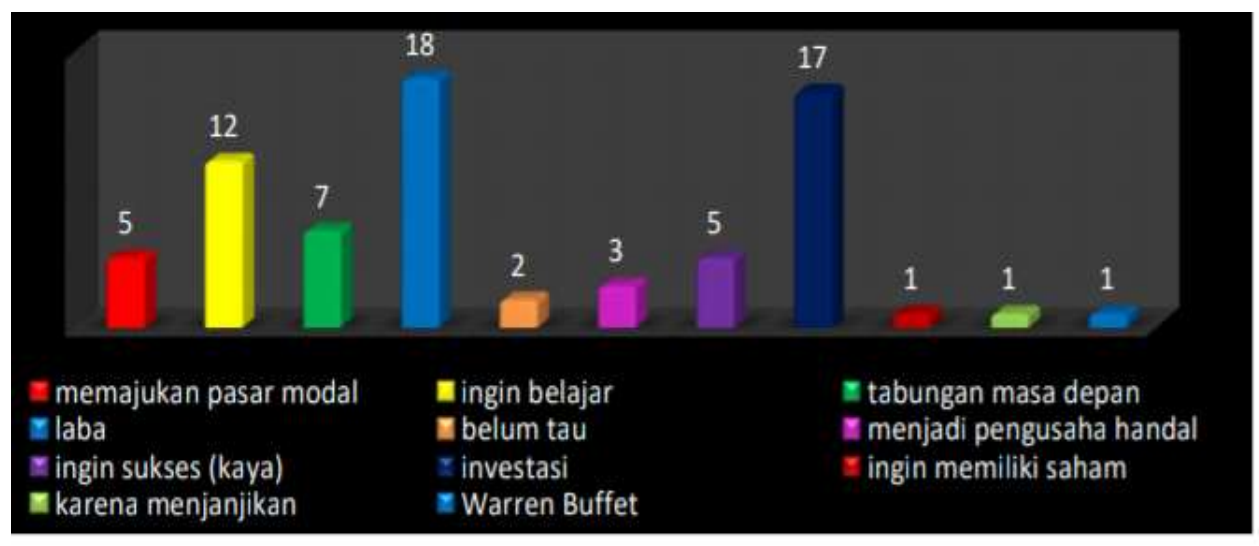

Berdasarkan data tersebut, ada beberapa faktor yang menjadikan responden berminat untuk investasi di pasar modal syariah. Faktor tersebut meliputi memajukan pasar modal di Indonesia, ingin lebih tahu (belajar), untuk tabungan masa depan (jangka panjang), ingin mendapatkan keuntungan (laba), karena belum tahu sehingga rasa ingin tahu muncul, ingin menjadi pengusaha (investor) sukses, ingin sukses (kaya), ingin 
berinvestasi, ingin memiliki saham, karena menjanjikan, dan weren buffet (karena terinspirasi tokoh).

Fakor yang memotivasi paling tinggi adalah keinginan untuk mendapatkan laba, diikuti dengan keinginan untuk beinvestasi, dan kemudian keinginan untuk belajar. Keinginan untuk memperoleh keuntungan (gain), dibagi ke dalam dua hal yaitu dividen atau capital gain. $71 \%$ responden termotivasi investasi di pasar modal syariah adalah agar mendapatkan dividen. Sementara sisanya $29 \%$ termotivasi untuk mendapatkan capital gain. Dalam rangka berinvestasi para responden memilih berbagai instrumen yang paling diinginkan. Instrumen tersebut dipilih sebagai wadah untuk investasinya. Adapun berbagai instrumen yang dipilih oleh para responden adalah sebagai berikut.

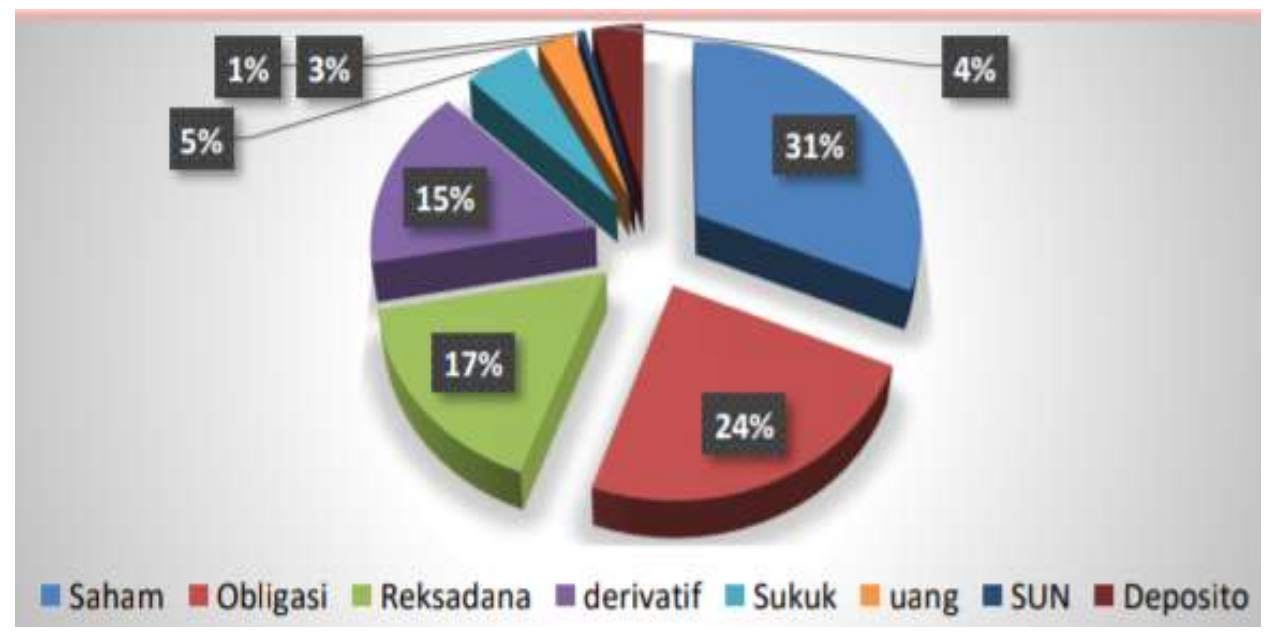

Data tersebut memuat beberapa pilihan, berdasarkan gambar di atas nampak jelas bahwa responden sebanyak $31 \%$ memilih saham sebagai pilihan untuk investasi. Pilihan berikutnya adalah obligasi, yaitu sebanyak $24 \%$, dan diikuti oleh reksadana sebesar 17\%, kemudian derivative (right issue, waran, dan opsi) $15 \%$. Sukuk menempati pilihan berikutnya, yaitu 55 responden memilih sukuk sebagai wadah investasinya. Pilihan berikutnya 
adalah instrumen di luar pasar modal, yaitu uang (valas) 4\%, SUN adalah $1 \%$, dan deposito sebanyak $4 \%$. Namun demikian, sosialisasi dan edukasi yang sudah terlaksana masih belum signifikan dalam membangun minat investasi mahasiswa. Hal ini dikarenakan banyak faktor yang penghambat minat investasi tersebut. Berbagai faktor yang menghambat diantaranya sebagai berikut.

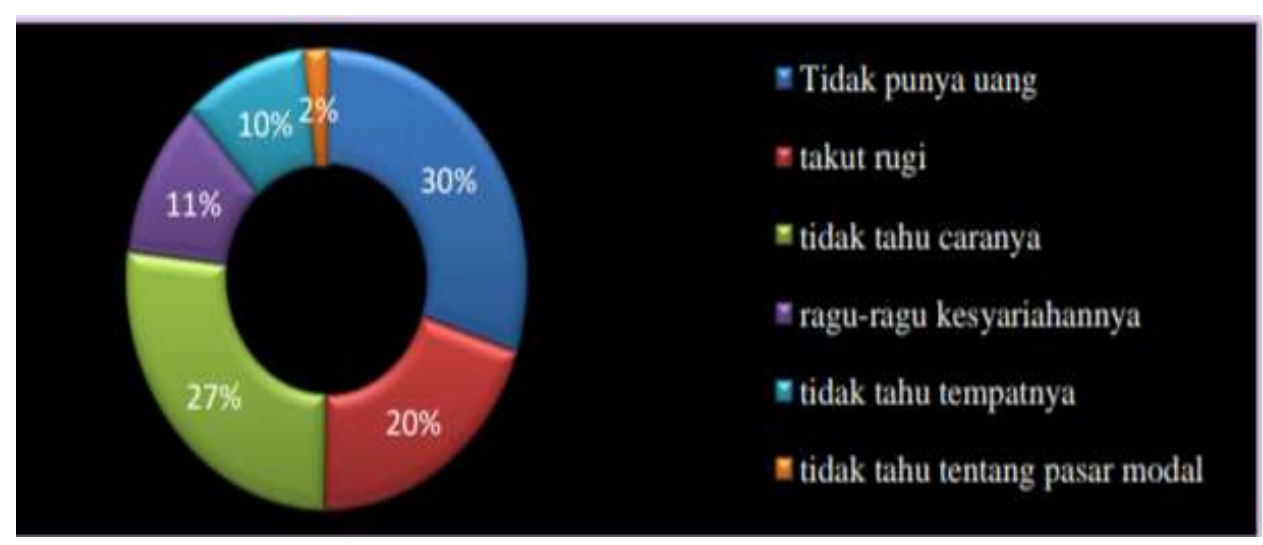

Berdasarkan gambar di atas menunjukkan bahwa faktor yang menghambat tertinggi adalah tidak memiliki modal (uang) untuk membuka rekening, dan juga untuk memulai investasi tersebut. Faktor kedua yaitu minimnya pengetahuan tentang pasar modal syariah, terutama cara berinvestasi. Faktor ketiga adalah takut akan resiko yang dihadapi atau takut mengalami kerugian. Faktor keempat adalah masih ragu-ragu dengan kesyariahannya. faktor kelima tidak tahu tempatnya (tempat untuk berinvestasi), dan faktor yang keenam adalah tidak tahu sama sekali tentang pasar modal syariah.

Solusi terhadap faktor penghambat di atas antara lain dengan meningkatkan dan mengoptimalkan sosialisasi dan edukasi pasar modal syariah, menurunkan modal untuk berinvestasi oleh sekuritas menjadi solusi untuk tidak adanya modal; melakukan simulasi atau trading langsung 
dengan modal yang ringan; strategi mengoptimalkan sosialisasi dan edukasi adalah dengan cara memanfaatkan berbagai informan dan media sosial.

\section{Kesimpulan}

Investasi pada umumnya merupakan suatu istilah dengan beberapa pengertian yang berhubungan dengan keuangan dan ekonomi, to use (money) make more money out of something that expected to increase in value. Istilah tersebut berkaitan dengan akumulasi suatu bentuk aktiva dengan harapan mendapatkan keuntungan di masa depan. Investasi disebut juga sebagai penanaman modal.

Investasi syariah adalah sebuah investasi berbasis syariah yang menggunakan instrumen Islam dalam pelaksanaannya. Ada beberapa jenis investasi berdasarkan jangka waktu, resiko dan prosesnya. Hal-hal tersebut perlu diketahui guna memastikan ketepatan antara alasan dan cara melakukan investasi. Perbedaan investasi syariah dengan konvensional, investasi syariah menggunakan sistem bagi-rugi hasil (mudharabah) sedangkan konvensional menggunakan sistem bunga. Khusus untuk saham, keuntungan yang didiapat berupa capital gain dan dividen.

Kegagalan beinvestasi disebabkan oleh banyak hal, diantaranya adalah faktor keamanan, ketertiban hukum, dan lain-lain. Pada umumnya resiko investasi dibagi menjadi dua macam resiko utama, yaitu capital loss dan risiko likuiditas.

Perkembangan pasar modal syariah, salah satunya didukung oleh peranan berbagai pihak terutama dalam melakukan sosialisasi dan edukasi. Sosialisasi dan edukasi dilakukan untuk masyarakat, baik institusi maupun perorangan, dan sosialisasi secara nasional maupun internasional. Tujuan sosialisasi dan edukasi, salah satunya adalah untuk meningkatkan investor di pasar modal. Di samping juga untuk meningkatkan kepercayaan investor terhadap pasar modal syariah. 


\section{Referensi}

Achsien, Iggi. Investasi Syariah di Pasar Modal. 2003. Jakarta, PT Gramedia Pustaka Utama.

Aziz, Abdul \& Mariyah Ulfah. Kapita Selekta Ekonomi Islam Kontemporer. 2010. Bandung, Alfabeta.

Aziz, Abdul. Manajemen investasi syariah. 2010. Alfabeta, Bandung.

Belouafi, Ahmed dan Abdelkader Chachi. 2014. Islamic Finance in the United Kingdom:Factor Behind it Development and Growth, Islamic Economic Studies (Keuangan Islam di Inggris: Faktor dibalik Perkembangan dan Pertumbuhannya) Vol. 22, No. 1.

Direktorat Pasar Modal Syariah Otoritas Jasa Keuangan. 2015. Roadmap Pasar Modal Syariah 2015-2019 ; Membangun Sinergi untuk Pasar Modal Syariah yang Tumbuh Stabil, dan Berkelanjutan.

Ganjar Isnawan. Jurus Cerdas Investasi Syariah. 2012. Jakarta, Laskar Aksara, 2012.

Gunawan, Pengaruh Analisis Fundamental Terhadap Harga Saham (Studi Empiris Terhadap Saham-Saham Syariah di Jakarta Islamic Indeks), Jurnal Wira Ekonomi Mikroskil, 1 April 2011, hlm. 47-58

Huda, Nurul \& Mustafa Edwin Nsution, Investasi Pasar Modal Syariah. 2008. Jakarta, Kencana Prenada Media Group.

Irvani, Ahmad. 2016. Inggris Sebagai Sentral Keuangan Islams di Barat, ASY-SYAR ${ }^{\mathrm{ee}}$ IYYAH, Vol. 1 No. 1.

Jogiyanto. Teori Fortofolio dan Analisis Investasi. 2003. Yogyakarta, BPFE

Kettani, M. Ali. 2005. Minoritas Muslim di Dunia Dewasa Ini, terj. Zarkowi Soejoeti. Jakarta: PT. Raja Grafindo Persada

Konsultan Hukum Ekonomi Syariah, Asuransi Islam Takaful Permintaan dan Penawaran di Inggris. 28 Oktober 2018

Latifah, Nur Aini. Konsep dan Aplikasi Asuransi Syariah di Indonesia. 30 September 2018.

Masrifah, Eva. 2010. "Analisis Pengembangan Produk Takaful Mikro Syariah", Skripsi S-I Kearsipan Fakultas Syariah Dan Hukum Universitas Islam Negeri Syarif Hidayatullah.

Mubarok, Ferry Khusnul. Peran Sosialisasi dan Edukasi dalam Menumbuhkan Minat Investasi di Pasar Modal Syariah, Jurnal Inovasi, 14 (2) 2018, 113-122. 
Nizar, Chairul, Abu Bakar Hamzah, Sofyan Syahnur, Pengaruh Investasi dan Tenaga Kerja Terhadap Pertumbuhan Ekonomi Serta Hubungannya Terhadap Tingkat Kemiskinan di Indonesia, Jurnal Ekonomi Pascasarjana Universitas Syah Kuala, Volume I, No.2, November 2019.

Roadmap Pasar Modal Indonesia 2015-2019 (Online) (http://www.ojk.go.id, diakses 2 November 2019)

Supriyadi \& Hariyanto, Faktor Pertimbangan Masyarakat Memilih Daftar Efek Syariah. Jurnal Manajemen Motivasi, 13 (No. 1), 2016, hlm. 802-806.

Tendelilin, Eduardus. 2001. Analisis Investasi dan Manajemen portofolio. Yogyakarta : BPFE

Yanti, M. Ubud, S, Made, S, \& Djumahir, , Determinan Price Ratio dan Stock Return (Studi pada Saham-Saham Syariah di Bursa Efek Indonesia). Jurnal Aplikasi Manajemen, 10(66), 2012, 273-290 